1929 were $£ 160,930,000, £ 60,304,000$, and $£ 100,626,000$. In 1929 the slump set in, affecting all the main iron and steel producing countries alike, and the world production of steel fell from $118,300,000$ tons in 1929 to $93,330,000$ in 1930 and $69,590,000$ in 1931. In the United States, with its high tariff, the fall was no less than 54 per cent. At the conclusion of his survey, Prof. Bone remarks that, "in view of the foregoing facts, which demonstrate beyond dispute not only how great has been the value of our vast export trade in iron and steel commodities within recent years, but also the ineffectiveness of tariffs to protect a country against the effects of a world-wide 'slump', the Government may well hesitate about adopting any measures calculated to raise steel prices to home consumers". " "Some temporary measure of relief may be necessary to tide over the present emergency, but such measures should be safeguarded so that the dependent export industries shall not suffer through enhanced prices."

\section{The Plant in Relation to Water*}

$\mathrm{T}$

HE study of plant life in arid regions has more than an academic interest. It throws important light on the relation of plants in general to their water supply. All things being equal, the plant is most valuable to man either as a crop or as forage when it gives the greatest yield with the least expenditure of water.

An arid region is not constantly hot and dry. It is one of extremes of climate. Plants growing there are not always faced with water shortage; at times they have enough and to spare. Nor are they always growing under a high temperature; extremes of cold have to be met as well as heat. The plants growing in dry regions are not of uniform type but very varied. A large proportion of the species are not drought resistant at all, and grow flowers during occasional dry spells, then die off. The succulent type, familiar through the cacti, with great stores of water which they expend very slowly, are peculiar and very rare in the natural flora of many dry countries. In Australia they are practically absent, and it is only a strictly limited area of light rainfall country that is threatened by the pest pear, not the great arid areas in South, Central, or Western Australia. The seriousness of the prickly pear is its menace to land that is good pastorally, not the danger to the more arid parts.

The various hard-leaved shrubs and trees of the dry country flora are plants of a type suited to climatic extremes. A curious feature of the Australian flora is that the shrubs and trees over most of the continent are of the hard-leaved type. This is the case even in the Sydney district, where the rainfall is good and the loss by evaporation annually is less than the rainfall. The hard-leaved structure does not mean that these plants are necessarily economical of water all the time, but that they can undergo more or less prolonged dry periods without injury.

In studying the drought resistance of various crop and fodder plants, some surprising results have emerged so far as the water requirements are concerned; thus, lucerne is about three times as lavish with its water as is sorghum in order to produce the same weight of dry material. The fact is that no single basis for drought resistance is known. The success or failure of a plant for economic purposes cannot be judged by its economical use of water alone. Even more important is its ability to remain active while water is running short and to survive dry spells.

* From the presidential address to the Linnean Society of New South * From the presidential address to the Linnean society

No. 3264, VoL. 129]

\section{University and Educational Intelligence}

Cambridge.-Dr. G. P. Bidder has given 5000 lire, with the promise of a like sum next January, for the benefit of the occupants of the Cambridge table at the Zoological Station at Naples.

Mr. N. F. Mott, of Gonville and Caius College, has been appointed University lecturer in the Faculty of Mathematics.

The General Board has, on the recommendation of the Faculty Board of Mathematics, conferred the title of Stokes lecturer in mathematics on Dr. P. A. M. Dirac.

Dublin.--Dr. T. J. Nolan, State Chemist, Irish Free State, has been appointed professor of ehemistry in University College, Dublin. Dr. Nolan took over his new appointment on May 1.

MANCHESTER.-The honorary degrees conferred at the commemoration of Founders' Day included the following :-D.Sc.: Sir James Jeans; LL.D.: Lord Rutherford, Sir Arthur Salter, and Dr. W. D. Ross.

OXFORD.-The preamble of the statute establishing a final honour school of geography was moved in Congregation on May 10 by Mr. C. G. T. Morison, student of Christ Church, and carried without a division. Mr. Morison laid stress on the necessity of an adequate scientific equipment for candidates in the school, with the view of providing which many different bodies have had to be consulted. The establishment of this examination will remove certain disadvantages under which graduates of Oxford have suffered in comparison with those of other universities.

THE Rockefeller Foundation, New York, U.S.A., has published the twentieth series of "Methods and Problems of Medical Education". It deals with many departments of study in medical schools in all parts of the world. The volume contains a number of admirable illustrations of the buildings and laboratories described, in many cases accompanied with plans to scale. The articles are not copyrighted, and may be reprinted or utilised in any manner without permission.

THe first award of the Swan Memorial Scholarship, established as a national memorial to Sir Joseph Wilson Swan, will be made this year by the council of the Institution of Electrical Engineers. The Swan Memorial Fund, the interest from which is devoted to the scholarship, was subscribed through the initiative of a committee composed of representatives of the County Borough of Sunderland, which was Swan's birthplace, and the Institution of Electrical Engineers. The scholarship has an approximate value of $£ 140$, and is tenable for one year. Candidates must be British subjects, less than twenty-seven years of age on July 1, and preference will be given to those associated with the County Borough of Sunderland. Awards of the following scholarships will also be made this year :-Duddell Scholarship : annual value $£ 150$ for three years, age limit, nineteen years; Ferranti Scholarship, annual value $£ 250$ for two years, age limit, twenty-six years; Silvanus Thompson Scholarship, annual value $£ 100$ and tuition fees, age limit, twenty-two years, for two years, for works employees. Applications (specifically mentioning the name of the scholarship) for particulars of any of these scholarships should be addressed to the Secretary of the Institution, Savoy Place, London, W.C.2. 